\title{
Type of constructed wetlands influence nutrient removal and nitrous oxide emissions from greenhouse wastewater
}

\author{
V. Lévesque ${ }^{1}$, H. Antoun ${ }^{1}$, P. Rochette ${ }^{2}$ and M. Dorais ${ }^{3}$ \\ ${ }^{1}$ Department of Soils and Agri-Food Engineering and Centre de recherche et d'innovation sur les végétaux, Faculté des \\ Sciences de l'agriculture et de l'alimentation, Université Laval, Quebec City, Canada \\ ${ }^{2}$ Quebec Research and Development Centre, Agriculture and Agri-Food Canada, Quebec City, Canada \\ ${ }^{3}$ Département de phytologie, Centre de recherche et d'innovation sur les végétaux, Faculté des Sciences de l'agriculture et \\ de l'alimentation, Université Laval, Québec, Canada
}

\section{Summary}

In the current study, three constructed wetlands (CWs) were tested as a sustainable method of treating highly ion charged greenhouse wastewater before disposal. Because of their anaerobic conditions, it was hypothesized that free water surface flow (FWS) and horizontal-subsurface flow (HSS) CWs would be more efficient at removing $\mathrm{NO}_{3}{ }^{-}$and $\mathrm{SO}_{4}{ }^{2-}$ from greenhouse wastewater than the vertical-flow (VSS) CW, but that FWS and HSS would emit more greenhouse gases. To test this hypothesis and propose the most sustainable CW for the greenhouse industry, this study compared three types of CWs (FWS, HSS and VSS) for their nutrient removal performance and nitrous oxide $\left(\mathrm{N}_{2} \mathrm{O}\right)$ emissions. The experiment was conducted in a greenhouse and consisted of 36 wetland units (12 replicates) of $0.8 \mathrm{~m}^{3}$ operated with reconstituted greenhouse wastewater enriched with sucrose (C:N ratio of 2.9) at a 10-day hydraulic retention time, corresponding to the effluent loading rate coming from commercial greenhouse vegetable crops. The CWs were filled with water (FWS), gravel (HSS), or sand (VSS) and planted with Eichhornia crassipes (FWS) or Typha latifolia (HSS, VSS), two macrophytes largely used to treat wastewaters heavily loaded in nutriment. Results showed that HSS performed better than the FWS and VSS at reducing pollutants from the greenhouse wastewater, with $45 \%$ total $\mathrm{N}$ load removed. Although $59 \%$ of the $\mathrm{NO}_{3}-\mathrm{N}$ load was removed in the FWS and HSS, a high accumulation of $\mathrm{NO}_{2}-\left(1.28 \mathrm{~g} \mathrm{~N} \mathrm{~m}^{-2} \mathrm{~d}^{-1}\right)$ occurred in FWS. The removal of ammonium $\left(\mathrm{NH}_{4}-\mathrm{N}\right)(\sim 26 \%)$ loadings was similar in all CWs. Only $4 \%$ of the $\mathrm{SO}_{4}-\mathrm{S}$ load was removed in the FWS and HSS, and no $\mathrm{SO}_{4}-\mathrm{S}$ reduction was observed in VSS. Mean cumulative $\mathrm{N}_{2} \mathrm{O}$ emissions were 7 and 59 times higher in FWS $\left(1.59 \mathrm{~g} \mathrm{~m}^{-2} \mathrm{~d}^{-1}\right)$ than in HSS and VSS, respectively. Although VSS emitted less $\mathrm{N}_{2} \mathrm{O}$ than the other CWs tested in this study, HSS was the best option in terms of reducing $\mathrm{CO}_{2}$ emissions and nutrient pollutants from greenhouse wastewater before disposal.

Keywords

greenhouse gases, nitrate, phosphate, sulfate, Typha latifolia, Eichhornia crassipes

\section{Significance of this study}

What is already known on this subject?

- Constructed wetland (CW) designs commonly used to treat wastewater are free water surface flow (FWS), horizontal-subsurface flow (HSS), and verticalsubsurface flow (VSS). However, it is not clear which CW system is the best sustainable option to treat greenhouse effluents, very rich in nutrients and low in dissolved organic carbon.

What are the new findings?

- The performance of three well-proven CW designs was compared within a robust experimental design. HSS performed better than FWS and VSS at reducing pollutants from the greenhouse effluent, while FWS showed a high accumulation of $\mathrm{NO}_{2}{ }^{-} \cdot \mathrm{N}_{2} \mathrm{O}$ emissions were 7 and 59 times higher in FWS than in HSS and VSS.

What is the expected impact on horticulture?

- The use of HSS constitutes a sustainable option to treat greenhouse effluents before disposal, while FWS causes important environmental burden in terms of $\mathrm{N}_{2} \mathrm{O}$ emissions. However, sufficient organic carbon should be provided to maintain a complete denitrification and reduction of sulfate.

\section{Introduction}

Greenhouse wastewater is rich in nutrients (e.g., $\mathrm{NO}_{3}{ }^{-}$, $\mathrm{PO}_{4}{ }^{3-}, \mathrm{SO}_{4}{ }^{2-}, \mathrm{Na}^{+}, \mathrm{Cl}^{-}$), as a result of intensive use of synthetic fertilizers in the irrigation water (e.g., $200-300 \mathrm{mg} \mathrm{N} \mathrm{L}^{-1}$, $50 \mathrm{mg} \mathrm{P} \mathrm{L}^{-1}$, and $200 \mathrm{mg} \mathrm{S} \mathrm{L}^{-1}$ ), but contains little dissolved organic carbon (DOC; 10 $\mathrm{mg} \mathrm{L}^{-1}$ ) (Gruyer et al., 2013a; Park et al., 2008; Prystay and Lo, 2001). The high $\mathrm{SO}_{4}{ }^{2-}$ concentration found in greenhouse wastewater is caused by a substantial use of potassium and magnesium sulfates as low sulfate content fertilizers are not always available or too expensive for producers. Therefore, when closed growing systems are used to recycle drained water in commercial greenhouses, preferential plant ion uptake leads to the buildup of $\mathrm{SO}_{4}{ }^{2-}$, resulting in an unbalanced nutrient solution (Dorais et al., 2001) (Table S1). Consequently, most growers using a closed system need to discharge around $20 \%$ of their unbalanced nutrient solution into the environment. For open growing systems, which are still in place in several countries, including Canada, pollutant ions such as $\mathrm{SO}_{4}{ }^{2-}, \mathrm{NO}_{3}{ }^{-}$and $\mathrm{PO}_{4}{ }^{3-}$ are 
released in the environment, which constitute important environmental burdens (Prystay and Lo, 2001). Like sulphur-containing fertilizers, $\mathrm{Na}^{+}$which is mainly related to the use of fertilizers such as $\mathrm{NaNO}_{3}$ or to the poor quality of the irrigation water also constitutes a major concern owing to their accumulation in the recycled nutrient solution which might reach damaging levels to crops (Rozema et al., 2014). Although $\mathrm{Na}^{+}$management is a key issue for some countries, the focus of this study is rather on the removal of $\mathrm{NO}_{3}-\mathrm{PO}_{4}{ }^{3-}$ and $\mathrm{SO}_{4}{ }^{2-}$ from greenhouse wastewater before releasing in the environment in order to reduce the environmental footprint of the greenhouse industry.

Technologies such as reverse osmosis and membrane filtration are available to remove undesirable ions, but the operating costs of those technologies are high. Over the last 25 years, constructed wetlands (CWs) have been considered a green, low-energy technique for wastewater treatment (Lee et al., 2009). The use of CWs may offer a sustainable and practical option for removing environmentally harmful nutrients (White, 2013) for open and closed growing systems and may replace the use of lagoons usually used to store the greenhouse effluent. It was also shown that CWs can constitute an efficient, safe and low-cost alternative to control pathogen infestations of greenhouse effluents compared to UV and thermic disinfection (Gruyer et al., 2013b), limiting risk associated to disease propagation when treated water is reused in the crop (Dorais et al., 2001).

Constructed wetlands are designed to take advantage of several processes involved in nutrient removal (Kadlec and Wallace, 2009). Sedimentation, precipitation, adsorption, and assimilation by plants contribute to CW performance, but transformation by microorganisms remains the key process, especially for nitrogen and sulfate. Soluble inorganic nutrients are removed via aerobic processes such as nitrification of $\mathrm{NH}_{4}{ }^{+}\left[\mathrm{NH}_{4}{ }^{+} \rightarrow \mathrm{NO}_{2}{ }^{-} \rightarrow \mathrm{NO}_{3}{ }^{-}\right]$and anaerobic processes such as denitrification of $\mathrm{NO}_{3}^{-}\left[\mathrm{NO}_{3}^{-} \rightarrow \mathrm{NO}_{2}^{-} \rightarrow \mathrm{NO} \rightarrow \mathrm{N}_{2} \mathrm{O} \rightarrow\right.$ $\mathrm{N}_{2}$ ] and reduction of $\mathrm{SO}_{4}{ }^{2-}\left[\mathrm{SO}_{4}{ }^{2-} \rightarrow \mathrm{H}_{2} \mathrm{~S}\right]$ (Reddy and DeLaune, 2008; Saeed and Sun, 2012). These processes are affected by the CW redox potential and the availability of electron donors. When the wastewater is low in labile organic carbon (C), such as greenhouse effluent, diverse sources of carbon are supplied to sustain anaerobic processes such as denitrification and $\mathrm{SO}_{4}{ }^{2-}$ reduction in CWs (Gagnon et al., 2010; Gruyer et al., 2013a; Park et al., 2008; Prystay and Lo, 2001).

The CW designs most commonly used to treat wastewater are free water surface flow (FWS), horizontal-subsurface flow (HSS), and vertical-subsurface flow (VSS) CWs (Lee et al., 2009; Vymazal, 2008a, b). The FWS are similar to wastewater ponds or lagoons found on commercial greenhouse facilities collecting run-off nutrient water with wastewater flowing shallowly over saturated soil substrate (Vymazal, $2008 \mathrm{~b}$ ). FWS offer a low construction cost and provide an anaerobic environment for denitrification (Lee et al., 2009; Vymazal, 2008b) and $\mathrm{SO}_{4}{ }^{2-}$ reduction (Postgate, 1984). Eichhornia crassipes is used in FWS (Wu et al., 2015), providing a large root area for microbial attachment and increasing denitrification potential when grown in lagoons filled with eutrophic wastewater (Gao et al., 2012; Yi et al., 2014).

Compared to FWS, those with subsurface flow have an advantage under cold climate because treatment occurs at warmer temperatures below the CW surface (Werker et al., 2002). Under a moderate temperature $\left(19^{\circ} \mathrm{C}\right)$, HSS were very efficient at removing heavy loads of $\mathrm{NO}_{3}^{-}\left(300 \mathrm{mg} \mathrm{L}^{-1}\right)$ and $\mathrm{SO}_{4}^{2-}\left(500 \mathrm{mg} \mathrm{L}^{-1}\right)$ from the greenhouse effluent by removing $95-98 \%$ of $\mathrm{NO}_{3}^{-}$and $98 \%$ of $\mathrm{SO}_{4}^{2-}$ (Gruyer et al., 2013a).
Although VSS were reported to be less efficient than HSS to remove $\mathrm{NO}_{3}{ }^{-}$load (Lee et al., 2009), large reductions in $\mathrm{NO}_{3}{ }^{-}$ $(86 \%), \mathrm{PO}_{4}^{3-}(100 \%)$, and $\mathrm{SO}_{4}{ }^{2-}(63 \%)$ were observed when greenhouse wastewater at the commercial level was treated in serial VSS during summer, fall, and winter in Eastern Canada (Lévesque et al., 2011). In HSS, a gravel bed (5 to $20 \mathrm{~mm}$ ) provides high hydraulic conductivity and poses low risks of clogging, whereas in VSS, sand ( 0.25 and $4 \mathrm{~mm})$ provides good contact between wastewater and bacteria growing on the medium (Vymazal, 2008a).

Phragmite australis (common reed) largely used in CWs is tolerant of high salinity (Vymazal, 2013a), while Typha latifolia (cattail) was found to be more tolerant to high $\mathrm{SO}_{4}{ }^{2-}$ concentrations present in greenhouse effluent (Lévesque et al., 2011). Maximum $\mathrm{Na}^{+}$uptake rates by macrophytes in wetland microcosms was estimated at $0.072 \mathrm{~g} \mathrm{~m}^{-2}$ day $^{-1}$, equivalent to less than $7 \%$ of the $\mathrm{Na}^{+}$removal from wastewater (Tanner, 1996). However, the macrophytes such as T. latifolia and E. crassipes were proven to have a good phytodesalinization potential of $\mathrm{Na}^{+}$in CWs environment (Rozema et al., 2014; Ajibade et al., 2013; Parwin and Paul, 2019).

Although removing nutrient pollutants from wastewater is essential in terms of disposed water quality, the emission of greenhouse gases (GHGs) such as $\mathrm{N}_{2} \mathrm{O}$ and $\mathrm{CH}_{4}$ from CWs should also be considered as they affect air quality. The production and emission of GHGs in CWs depend on redox potential and $\mathrm{N}$ and $\mathrm{C}$ contents, factors that are affected by the wastewater source and CW type (Kampschreur et al., 2009; Saeed and Sun, 2012). A meta-analysis of GHG losses from $\mathrm{CW}$ wastewater treatment systems concluded that $\mathrm{N}_{2} \mathrm{O}$ emissions were similar between CW types but were highly variable within each type (FWS, 0.1 to $15.6 \mathrm{mg} \mathrm{m}^{-2} \mathrm{~d}^{-1}$, average $3.1 \mathrm{mg} \mathrm{m}^{-2} \mathrm{~d}^{-1}$; VSS, 0.1 to $10.2 \mathrm{mg} \mathrm{m}^{-2} \mathrm{~d}^{-1}$, average $3.4 \mathrm{mg}$ $\mathrm{m}^{-2} \mathrm{~d}^{-1}$; HSS, 0.0 to $21.5 \mathrm{mg} \mathrm{m}^{-2} \mathrm{~d}^{-1}$, average $5.8 \mathrm{mg} \mathrm{m}^{-2} \mathrm{~d}^{-1}$ ) (Mander et al., 2014). Part of this variability was explained by the $\mathrm{NO}_{3}^{-}$and labile $\mathrm{C}$ concentrations in the wastewater, which affected the end products of denitrification. The $\mathrm{NO}_{3}^{-}$load of greenhouse wastewater (6.53-6.90 $\mathrm{g} \mathrm{N} \mathrm{m}^{-2} \mathrm{~d}^{-1}$ ) (Gagnon et al., 2010; Prystay and Lo, 2001) is typically much higher than the effluent loads from other agricultural sources (1-203 $\mathrm{mg} \mathrm{N} \mathrm{m}^{-2} \mathrm{~h}^{-1}$, equivalent to $0.02-4.87 \mathrm{~g} \mathrm{~N} \mathrm{~m}^{-2} \mathrm{~d}^{-1}$ ) (Mander et al., 2014; Vymazal, 2007), and the impact of such $\mathrm{NO}_{3}{ }^{-}$concentrations on $\mathrm{N}_{2} \mathrm{O}$ emissions from $\mathrm{CWs}$ is unknown (Kampschreur et al., 2009).

Even though the potential of CWs for treating various types of polluted water has been largely shown (Gao et al., 2012; Mander et al., 2014; Park et al., 2008; Saeed and Sun, 2012; Wu et al., 2014), it is still unclear which CW system is the best sustainable option for greenhouse effluents. According to the fertilizer commonly used by greenhouse tomato growers, high concentrations of $\mathrm{NO}_{3}{ }^{-}, \mathrm{PO}_{4}{ }^{3-}$, and $\mathrm{SO}_{4}{ }^{2-}$ are found in crop effluents as shown by our one-year sampling at commercial greenhouses located in Eastern Canada (Table S1). The objective of the present study was to compare the performance of FWS, HSS, and VSS, with well-proven CW designs of published studied, for the removal of $\mathrm{NO}_{3}{ }^{-}, \mathrm{PO}_{4}{ }^{3-}$, and $\mathrm{SO}_{4}{ }^{2-}$ found in greenhouse effluents and the reduction of $\mathrm{N}_{2} \mathrm{O}$ emissions in order to reduce the environmental impact of the greenhouse industry when producers need to discharge their unbalanced nutrient solution into the environment. Specifically, a low-cost FWS planted with E. crassipes was compared with HSS and VSS planted with T. latifolia and filled with gravel and sand, respectively. Because of the anaerobic conditions in FWS and HSS, it was hypothesized that those CWs would be more efficient at removing $\mathrm{NO}_{3}{ }^{-}$and 
$\mathrm{SO}_{4}{ }^{2-}$ in greenhouse wastewater than VSS, but that FWS and HSS would emit more GHGs.

\section{Materials and methods}

\section{Experimental set-up}

A total of 36 CWs (height, $0.71 \mathrm{~m}$; length, $1.44 \mathrm{~m}$; width, $0.86 \mathrm{~m}$ ) were established in December 2008 in a Venlo-type greenhouse $\left(150 \mathrm{~m}^{2}\right)$ located at Laval University (Quebec City, QC, Canada, $46^{\circ} 46^{\prime} \mathrm{N}, 71^{\circ} 16^{\prime} \mathrm{W}$ ). The dimensions of CWs selected in this study were based according to the previous studies presented in the literature treating greenhouse wastewater (Gruyer et al., 2013a; Gagnon et al., 2010).

The greenhouse air temperature and vapor pressure deficit were maintained at $19.8 \pm 0.7^{\circ} \mathrm{C}$ and $1.56 \pm 0.08 \mathrm{kPa}$, respectively, during the experiment (March to October 2009), and the average temperature of the CWs was $22.1 \pm 0.3^{\circ} \mathrm{C}$. Three well-proven designs of CWs were compared (Figure 1): FWS, which was areas of open water planted with E. crassipes, a free-floating plant; HSS, which was filled with river
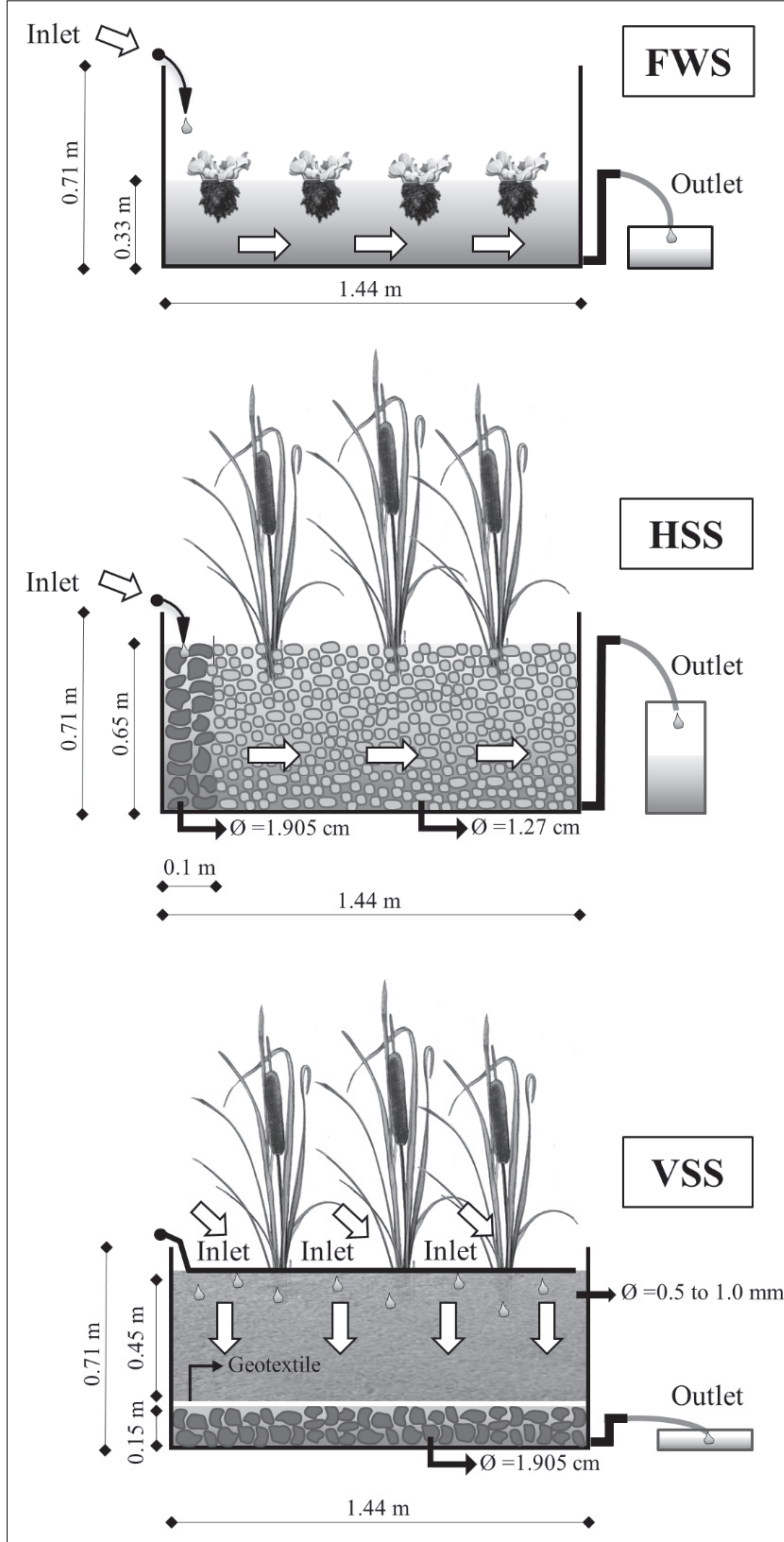

FIGURE 1. Section view of the three constructed wetlands used in this study: free water surface flow (FWS), horizontalsubsurface flow (HSS), and vertical-subsurface flow (VSS). gravel ( $\varnothing 1.27 \mathrm{~cm} ; 40 \%$ porosity) with a 10 -cm section at the inlet filled with coarse gravel ( $\varnothing 1.905 \mathrm{~cm} ; 48 \%$ porosity) and were planted with T. latifolia; and VSS CWs, which was filled with $15 \mathrm{~cm}$ of coarse gravel ( $\varnothing 1.905 \mathrm{~cm} ; 48 \%$ porosity) and $45 \mathrm{~cm}$ of sand ( $\varnothing 0.5-1 \mathrm{~mm} ; 32.5 \%$ porosity) separated by a geotextile and were planted with T. latifolia. The T. latifolia rhizomes were planted at the same time of the establishment of CWs in December 2008 and were spaced $15 \mathrm{~cm}$ apart. The E. crassipes were previously grown in a pond and five free-floating plants were transferred in the each FWS at the establishment of CWs. The CWs were placed in three random blocks, each containing four randomly placed CWs per treatment for a total of 12 experimental units per block and 12 replicates per treatment.

To simulate commercial greenhouse-irrigation management (batch feeding system), seven irrigation events (15 min per irrigation) were applied during the day. Wastewater was distributed to each unit using pipes $(5 / 3 \mathrm{~mm})$ connected to angled-arrow drippers (FWS and HSS) or drip tape (VSS) for a total of $30 \mathrm{~L} \mathrm{~m}^{-2} \mathrm{~d}^{-1}$ (FWS), $26 \mathrm{~L} \mathrm{~m}^{-2} \mathrm{~d}^{-1}$ (HSS), or $22 \mathrm{~L} \mathrm{~m}^{-2} \mathrm{~d}^{-1}$ (VSS), corresponding to a commonly used irrigation frequency for greenhouse vegetable crops. This inlet loading was different for each CW in order to ensure the same hydraulic retention time, $10 \mathrm{~d}$, for all treatments. This hydraulic retention time was chosen because it was shown to be efficient for treating greenhouse wastewater (Prystay and Lo, 2001) and was representative of the commercial volume of wastewater that has to be treated. Hydrolytic pumps connected to timers-controlled wastewater addition, and the number of drippers or drip tapes controlled the volume added to each type of CW.

Based on average analyses of wastewater sampled for one year in commercial tomato greenhouses located in Eastern Canada, reconstituted greenhouse wastewater was made (Table S1). No sodium fertilizer, such as $\mathrm{NaNO}_{3}$ was used as nutrient for tomato growth. Therefore, this element was not considered in the reconstituted greenhouse wastewater of this study. Because greenhouse effluents are low in organic C to carry out heterotrophic denitrification, sucrose was added at the inlet of each CW to maintain a C: $\mathrm{N}$ ratio of 2.9 (i.e., $400 \mathrm{mg}$ sucrose $\mathrm{L}^{-1}: 139.1 \mathrm{mg}$ total $\mathrm{N} \mathrm{L}^{-1}$ ), which falls within the reported optimal range for $\mathrm{N}$ removal efficiency (Misiti et al., 2011; Zhao et al., 2010).

\section{Chemical and physical analyses}

Every week, inlet and outlet samples (24-h composite samples of $50 \mathrm{~mL}$ ) were collected for each of the $36 \mathrm{CWs}$. Concentrations of $\mathrm{NO}_{3}{ }^{-}, \mathrm{NO}_{2}{ }^{-}, \mathrm{SO}_{4}{ }^{2-}$, and $\mathrm{Cl}^{-}$were determined using the Dionex ICS-2000 ion chromatography system (IonPac AS18 column and AG18 pre-column; Sunnyvale, CA, United States), and $\mathrm{PO}_{4}{ }_{4-}$ concentration was measured spectrophotometrically (Hitachi model U-1100 UV/vis w/cell; Tokyo, Japan) as described by Murphy and Riley (1962). Every two weeks, $\mathrm{NH}_{4}{ }^{+}, \mathrm{K}^{+}$, and $\mathrm{Ca}^{2+}$ were determined using Cole Parmer specific electrodes (Montreal, QC, Canada), and $\mathrm{Mg}^{2+}$ was determined by atomic absorption spectrometry (Perkin Elmer model 3300; Waltham, MA, United States). Total nitrogen (TN) was calculated as the sum of the three $\mathrm{N}$ forms measured $\left(\mathrm{NO}_{3}{ }^{-}, \mathrm{NO}_{2}{ }^{-}\right.$, and $\left.\mathrm{NH}_{4}{ }^{+}\right)$.

Starting in the third week of the experiment, chemical oxygen demand (COD) and biochemical oxygen demand $\left(\mathrm{BOD}_{5}\right)$ were determined every two weeks, as described in APHA (2005). Both $\mathrm{BOD}_{5}$ and COD were measured in the inlets before entering CWs and in the outlets. The temperature in each CW was measured at a $10-\mathrm{cm}$ depth using a thermo- 
couple, and the values were averaged each hour (CR10X data logger; Campbell Scientific, Logan, UT, United States). On every sampling date, inlet and outlet volumes of water were measured for each CW unit. To get an accurate estimation of performance for the three types of CWs, inlet or outlet nutrient loading per day $\left(\mathrm{g} \mathrm{m}^{-2} \mathrm{~d}^{-1}\right)$ were calculated from the raw data by using the nutrient concentrations and the total daily volumes of water measured at the $\mathrm{CW}$ inlet and outlet according the following equations:

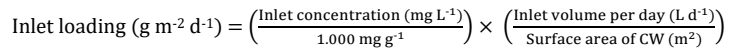

The percentage of loading removal was calculated with the values of inlet and outlet loading according the following equation:

Loading removal $(\%)=\left[1-\left(\frac{\text { Outlet loading }\left(\mathrm{g} \mathrm{m}^{-2} \mathrm{~d}^{-1}\right)}{\text { Inlet loading }\left(\mathrm{g} \mathrm{m}^{-2} \mathrm{~d}^{-1}\right)}\right)\right] \times 100$

Cumulative $\mathrm{NO}_{3}^{-}$and $\mathrm{NO}_{2}^{-}$exposure, an integrated measure of nutrients in each CW over time and representing the exposure of the CW microbial population to nitrogen (Burton et al., 2008), was calculated using a linear interpolation of the variation in nutrient $\left(\mathrm{NO}_{3}-\mathrm{N}\right.$ and $\left.\mathrm{NO}_{2}-\mathrm{N}\right)$ loading between the outlet and inlet of CWs among sampling dates.

\section{Measurements of gas emissions}

Starting in the third week of the experiment, emissions of $\mathrm{N}_{2} \mathrm{O}, \mathrm{CO}_{2}$, and $\mathrm{CH}_{4}$ from the CWs were measured every two weeks, before the first daily irrigation, using non-flowthrough non-steady-state chambers (Rochette and Bertrand, 2008). Briefly, a clear acrylic frame (height, $0.14 \mathrm{~m}$; width, $0.15 \mathrm{~m}$; length, $1.33 \mathrm{~m}$ ) was inserted in each $\mathrm{CW}$ to a depth of $4 \mathrm{~cm}$ under the water in FWS (maintained with cables), $10 \mathrm{~cm}$ under the gravel surface in HSS, and $8 \mathrm{~cm}$ under the sand surface in VSS, to ensure good airtightness, and was left in place during the experiment. To avoid errors in gas measurement, plant leaves present inside the frame were removed on the day before gas sampling. At the time of measurement, an insulated and vented $15-\mathrm{cm}$-high chamber was tightly attached to the top of the frame. Air samples $(20 \mathrm{~mL})$ were taken through a rubber septum using a syringe at 0,12 , 24 , and 36 min after chamber deployment and transferred into pre-evacuated vials (12-mL Exetainer vials; Labco, High Wycombe, BUX, England). Gas concentrations were determined within $7 \mathrm{~d}$ with a gas chromatograph equipped with an electron capture detector (Model 3800; Varian Inc., Walnut Creek, CA, United States) and a headspace autoinjector (Combi PAL; CTC Analytics, Zurich, Switzerland). Gas emissions were calculated according to the equation of $\mathrm{N}_{2} \mathrm{O}-\mathrm{N}$ flux (Rochette and Bertrand, 2008). Flux measurements were performed on four randomly selected replicates for each type of CW, and cumulative gas emissions were calculated by linear interpolation between sampling dates.

\section{Microbial analysis}

Outlet samples $(50 \mathrm{~mL})$ were collected twice a month in each of the $36 \mathrm{CWs}$ for the estimation of the microbial population using the most-probable-number technique. Bacto tryptic soy broth (BD, Mississauga, ON, Canada) was used to estimate aerobic microorganisms, whereas the growth medium for denitrifiers was prepared as described by Kern and Idler (1999). Water samples were subjected to tenfold serial dilution in $0.1 \mathrm{M} \mathrm{MgSO}_{4}$, and a five-microtube most-probable-number series was used. Each 1.5-mL microtube containing $900 \mu \mathrm{L}$ of culture medium received $100 \mu \mathrm{L}$ of the diluted sample. The microtubes were incubated at $22^{\circ} \mathrm{C}$ for 24 $\mathrm{h}$ for aerobic microorganisms and for $14 \mathrm{~d}$ for denitrifiers. The growth of aerobic microorganisms was assessed visually by the presence of turbidity. The number of denitrifiers was assessed by determining the presence of $\mathrm{NO}_{3}^{-}, \mathrm{NO}_{2}^{-}$, or both by adding diphenylamine-sulfuric acid coloring reagent and recording the number of positive and negative denitrification reactions (McCarty et al., 2007). The total microbial enzymatic activity was measured by hydrolysis of fluorescein diacetate (FDA) according to the method of Adam and Duncan (2001).

\section{Statistical analysis}

The data were analyzed according to a randomized complete block design with 12 replicates and processed by Proc Mixed (repeated measures) in the SAS software package (v. 9.1, 2002-2003; SAS Institute Inc., Cary, NC, United States). Cumulative $\mathrm{N}_{2} \mathrm{O}$ and $\mathrm{CO}_{2}$ fluxes were normalized prior to analyze using natural logarithms and square root transformations, respectively. The three types of CWs were compared for $\mathrm{pH}$ and electrical conductivity, mineral concentrations, mineral loadings, cumulative gas emissions, and FDA hydrolysis. The differences between means were established by Tukey's test $(P \leq 0.05)$. Pearson's product-moment correlation was performed to assess the linear relationship between two normally distributed interval variables.

\section{Results and discussion}

Temperature, electrical conductivity, and $\mathrm{pH}$ in each type of CW were constant during the experiment (data not shown), suggesting that the three months of adaptation prior to the start of this study had allowed the CWs to reach their steady state. The outlet $\mathrm{pH}$ (6.3) from VSS effluent was significantly lower than FWS (7.1) and HSS (7.0), and was similar to the inlet $\mathrm{pH}$ (6.2) from greenhouse wastewater (Table S1). These $\mathrm{pH}$ were suitable for most mechanisms of $\mathrm{N}$ removal to proceed, with the exception of $\mathrm{NH}_{3}$ volatilization, being negligible at $\mathrm{pH}$ below 7.5 (Vymazal, 2007). Furthermore, nutrient removal performance of all CWs was stable during the 19-week experiment as shown in Figure 2 for $\mathrm{N}$ forms $(P>0.05)$. Therefore, nutrient removal analyses were performed for this time period.

Although E. crassipes were healthy at the establishment of the experiment and performs generally well in eutrophic water (Gao et al., 2012; Yi et al., 2014), the high $\mathrm{NO}_{2}^{-}$concentrations measured in FWS affected their growth, causing them to wither and die after eight weeks. No plant disease was observed. Consequently, results for microbial abundance and activity, and for GHGs were analyzed and presented separately for the first 8 weeks (period 1) and for week -9 to -19 (period 2) as significant differences were observed for $\mathrm{CO}_{2}, \mathrm{FDA}, \mathrm{COD}$ and $\mathrm{BDO}_{5}$ in FWS.

\section{Nitrogen removal}

The $\mathrm{NO}_{3}-$ removal was higher $(P \leq 0.05)$ in FWS and HSS than in VSS (Table 1). Because of their greater oxygen transfer capacity, VSS offer low conditions for denitrification (Vymazal, 2007), which explains the absence of $\mathrm{NO}_{3}{ }^{-}$removal from greenhouse wastewater. FWS and HSS removed 59\% of 


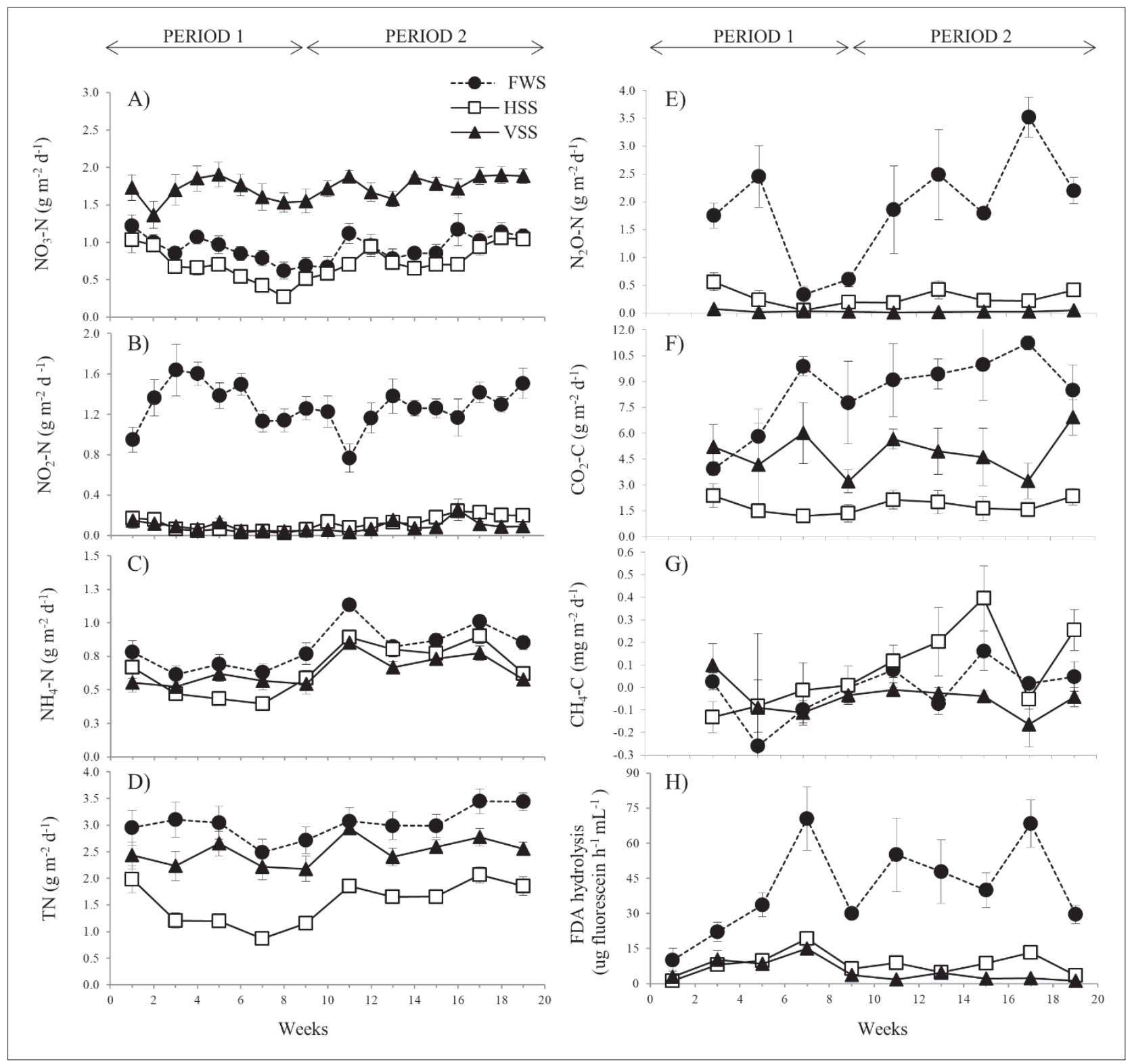

FigurE 2. Effluent nitrogen (A, B, C, D), gas emissions (E, F, G), and microbial activity as reflected by fluorescein diacetate (FDA) hydrolysis (H) for the three constructed wetlands studied: free water surface flow (FWS), horizontal-subsurface flow (HSS), and vertical-subsurface flow (VSS). Data are means \pm standard errors for outlet loadings of $\mathrm{NO}_{3}$; $\mathrm{NO}_{2}$; $\mathrm{NH}_{4}{ }^{+}$, and total nitrogen (TN) $(n=12), \mathrm{N}_{2} \mathrm{O}, \mathrm{CO}_{2}$, and $\mathrm{CH}_{4}$ fluxes $(n=4)$, and FDA hydrolysis $(n=6)$.

the $\mathrm{NO}_{3}-\mathrm{N}$ from the wastewater (Table 1 ), despite removal performance was higher $(P \leq 0.05)$ in FWS $\left(1.32 \mathrm{~g} \mathrm{~N} \mathrm{~m}^{-2} \mathrm{~d}^{-1}\right)$ than in HSS $\left(1.06 \mathrm{~g} \mathrm{~N} \mathrm{~m}^{-2} \mathrm{~d}^{-1}\right)$. This difference is related to the fact that the inlet loading was higher in FWS $\left(2.25 \mathrm{~g} \mathrm{~N} \mathrm{~m}^{-2} \mathrm{~d}^{-1}\right)$ than in HSS (1.76 $\left.\mathrm{g} \mathrm{N} \mathrm{m}^{-2} \mathrm{~d}^{-1}\right)$ in order to ensure a same retention time of $10 \mathrm{~d}$ in all CW types (Table 1). Prystay and Lo (2001) reported lower values $(13 \%-25 \%)$ for the treatment of greenhouse wastewater (50 $\mathrm{mg} \mathrm{N} \mathrm{L}^{-1}, 20 \mathrm{mg} \mathrm{DOC} \mathrm{L}^{-1}$ ) by HSS planted with T. latifolia. They attributed those low values to the low level of organic C. Indeed, higher removal rates (up to $72 \%$ ) was reported for HSS when sucrose $(726 \mathrm{mg}$ sucrose $\left.\mathrm{L}^{-1}\right)$ was added to greenhouse wastewater $\left(228 \mathrm{mg} \mathrm{NO}_{3}-\mathrm{N} \mathrm{L}^{-1}\right)$ (Gagnon et al., 2010).

Although the $\mathrm{NO}_{2}^{-}$inlet load was marginal in the CWs, the accumulation of $\mathrm{NO}_{2}^{-}$was found to be very high in the FWS outlet loading $\left(1.28 \mathrm{~g} \mathrm{~N} \mathrm{~m}^{-2} \mathrm{~d}^{-1}\right)$, while it was very low in HSS and VSS $\left(<0.12 \mathrm{~g} \mathrm{~N} \mathrm{~m}^{-2} \mathrm{~d}^{-1}\right)$ (Table 1$)$. The production of $\mathrm{NO}_{2}^{-}$in CWs was also observed in other studies (Alleman, 1985; Kampschreur et al., 2009; Kim et al., 2008). They have attributed this $\mathrm{NO}_{2}{ }^{-}$production to an incomplete nitrification because of the presence of high-free $\mathrm{NH}_{3}$ inhibition, a lag in the growth of $\mathrm{NO}_{2}$-oxidizing microbial populations at high pH levels (8.4 to 9.2), and slow $\mathrm{NO}_{2}{ }^{-}$oxidation under limiting $\mathrm{O}_{2}$ availability. In our study, we observed little free $\mathrm{NH}_{3}$ in the wastewater because of the slightly acidic conditions (Alleman, 1985). The absence of a typical high $\mathrm{NO}_{2}^{-}$peak (Figure 2B) in FWS associated with a lag in microbial growth (Figure $2 \mathrm{H}$ ) suggests that lower $\mathrm{O}_{2}$ concentration would have resulted in nitrification-related $\mathrm{NO}_{2}^{-}$production (Zhang et al., 2011). Lower $\mathrm{O}_{2}$ availability in the FWS is in line with the high concentrations of $\mathrm{COD}$ and $\mathrm{BOD}_{5}$ observed during the first 8-week experimental period (Figure S1) and with the high cumulative of $\mathrm{CO}_{2}$ emissions, which was two to eight times greater in FWS than in the other CWs (Figure 2F; Table 2). Higher $\mathrm{NO}_{2}$ - accumulation and $\mathrm{CO}_{2}$ emissions in FWS than in HSS and VSS (Figures 2B, F; Table 2) were observed not only in week -9 to -19 , when the dead E. crassipes biomass might have contributed to organic $C$ inputs, but also in the first 8 


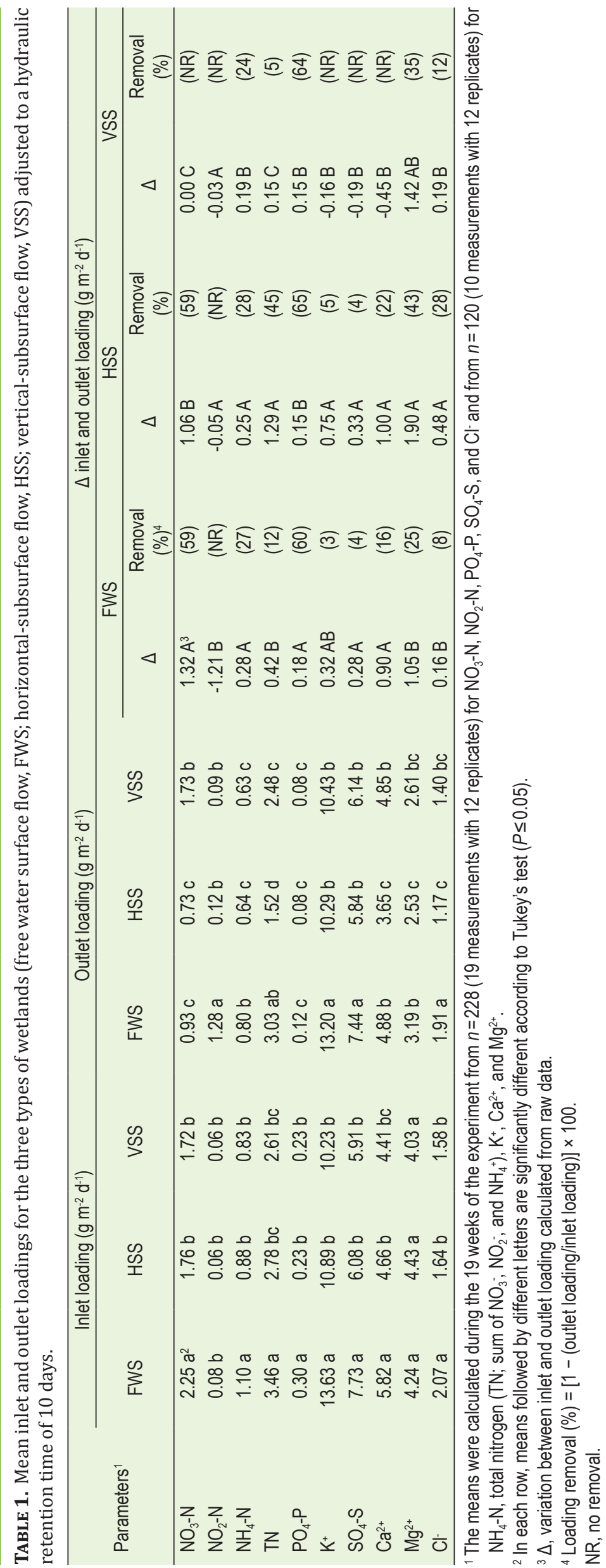

weeks, suggesting that E. crassipes was also a greater $\mathrm{C}$ source than $\mathrm{T}$. latifolia, likely via root exudates and turnover. No significant difference between HSS and VSS was observed for $\mathrm{NO}_{2}-\mathrm{N}$ accumulation (Table 1), while HSS had lower $\mathrm{CO}_{2}-\mathrm{C}$ accumulation, but higher $\mathrm{N}_{2} \mathrm{O}-\mathrm{N}$ accumulation than VSS (Table 2).

Nitrite can also accumulate under conditions that prevent complete $\mathrm{NO}_{3}^{-}$reduction, as observed in Table 1. Such situations were reported in wastewater with high availability of organic $\mathrm{C}$ or incomplete anaerobic conditions where $\mathrm{NO}_{3}{ }^{-}$is preferred to $\mathrm{NO}_{2}{ }^{-}$as the electron acceptor (Alleman, 1985; Kelso et al., 1999; Zhang et al., 2014). Although denitrification is a dominant process in $\mathrm{NO}_{3}$-rich environments with low $\mathrm{C}$ supplies, dissimilatory nitrate reduction to ammonium (DNRA) is a dominant process under high-C and $\mathrm{NO}_{3}$-rich conditions (Reddy and DeLaune, 2008). In previous studies, it was suggested that the accumulation of $\mathrm{NO}_{2}{ }^{-}$during the reduction of $\mathrm{NO}_{3}^{-}$from freshwater sediments rich in $\mathrm{C}$ originated predominantly from DNRA rather than from denitrification at sediment depths (Kelso et al., 1997, 1999). According to our study, the high amount of $E$. crassipes root detritus leaving more organic $C$ substrates in FWS may have promoted an anaerobic environment for the DNRA process in those CWs and contributed to the accumulation of $\mathrm{NO}_{2}$ :

The removal of $\mathrm{NH}_{4}{ }^{+}$varied from $24 \%$ for VSS to $27 \%$ and $28 \%$ for FWS and HSS, respectively (Table 1). These values are about half of the removal performance observed with CWs treating hydroponic wastewater (Gagnon et al., 2010) or greenhouse wastewater (Prystay and Lo, 2001). However, the $\mathrm{NH}_{4}{ }^{+}$inlet loading in our study, corresponding to the one observed at the commercial level during one year, was 1.8 times higher than that used by those authors $\left(\sim 0.94 \mathrm{~g} \mathrm{~N} \mathrm{~m}^{-2} \mathrm{~d}^{-1}\right.$ compared to $\left.0.51 \mathrm{~g} \mathrm{~N} \mathrm{~m}^{-2} \mathrm{~d}^{-1}\right)$. The VSS was, however, less efficient at removing $\mathrm{NH}_{4}{ }^{+}\left(0.19 \mathrm{~g} \mathrm{~N} \mathrm{~m}^{-2} \mathrm{~d}^{-1}\right)$ than HSS $\left(0.25 \mathrm{~g} \mathrm{~N}^{-}\right.$ $\left.\mathrm{m}^{-2} \mathrm{~d}^{-1}\right)$ and FWS $\left(0.28 \mathrm{~g} \mathrm{~N} \mathrm{~m}^{-2} \mathrm{~d}^{-1}\right)$ (Table 1$)$.

With respect to TN loading, the HSS were more efficient $(P \leq 0.05)$ at removing $\mathrm{N}$ from greenhouse wastewater than FWS and VSS (Figure 2D). In average, the HSS removed $45 \%$ of the three $\mathrm{N}$ forms measured $\mathrm{NO}_{3}{ }^{-}, \mathrm{NO}_{2}{ }^{-}$, and $\mathrm{NH}_{4}^{+}$), whereas the FWS removed $12 \%$, and the VSS removed only $5 \%$ (Table 1 ).

\section{Sulfate removal}

Only $4 \%$ of the $\mathrm{SO}_{4}^{2-}$ from the inlet loading $\left(\sim 6 \mathrm{~g} \mathrm{~S} \mathrm{~m}^{-2} \mathrm{~d}^{-1}\right)$ was removed in the FWS and HSS during the experiment, whereas VSS did not reduce any $\mathrm{SO}_{4}^{2-}$ (Table 1). In contrast to the studies performed by Gruyer et al. (2013a) who observed $95-98 \% \mathrm{NO}_{3}{ }^{-}$and $98 \% \mathrm{SO}_{4}{ }^{2-}$ removal from a reconstituted greenhouse wastewater (300 $\mathrm{mg} \mathrm{NO}_{3}{ }^{-} \mathrm{L}^{-1}$ and $500 \mathrm{mg} \mathrm{SO}_{4}{ }^{2-} \mathrm{L}^{-1}$ ) enriched with sucrose ( $2 \mathrm{~g}$ sucrose $\left.\mathrm{L}^{-1}\right)$ in HSS, the anaerobic environment and the limited source of $\mathrm{C}$ in our three studied CWs were not sufficient to en- 
TABLE 2. Mean cumulative fluxes of greenhouse gases from the three types of constructed wetlands (free water surface flow, FWS; horizontal-subsurface flow, HSS; verticalsubsurface flow, VSS) during two periods (period 1, first 8 weeks, $n=36$; period 2, weeks 9 to $19, n=72$ ).

\begin{tabular}{lrcl}
\hline & \multicolumn{3}{c}{ Flux $\left(\mathrm{mg} \mathrm{m}^{-2} \mathrm{~d}^{-1}\right)$} \\
\cline { 2 - 4 } & $\mathrm{N}_{2} \mathrm{O}-\mathrm{N}$ & $\mathrm{CO}_{2}-\mathrm{C}$ & $\mathrm{CH}_{4}-\mathrm{C}$ \\
\hline Period 11 & & & \\
FWS & $1266 \mathrm{a}^{2}$ & $6763 \mathrm{~b}$ & $<1_{\mathrm{NS}}$ \\
HSS & $191 \mathrm{~b}$ & $1410 \mathrm{~d}$ & $<1_{\mathrm{NS}}$ \\
VSS & $31 \mathrm{c}$ & $3116 \mathrm{C}$ & $<1_{\mathrm{NS}}$ \\
Period 2 & & & \\
FWS & $1906 \mathrm{a}$ & $9565 \mathrm{a}$ & $<1_{\mathrm{NS}}$ \\
HSS & $252 \mathrm{~b}$ & $1283 \mathrm{~d}$ & $<1_{\mathrm{NS}}$ \\
VSS & $22 \mathrm{C}$ & $4388 \mathrm{C}$ & $<1_{\mathrm{NS}}$ \\
\hline
\end{tabular}

${ }^{1}$ The mean of cumulative output was calculated during period 1 and period 2 on the measurement dates indicated in Figure 2.

2 In each column, means followed by different letters are significantly different according to Tukey's test $(P \leq 0.05)$.

NS, nonsignificant.

sure the $\mathrm{SO}_{4}{ }^{2-}$ reduction by sulfate-reducing bacteria. Denitrification is a process that is energetically more favorable than $\mathrm{SO}_{4}{ }^{2-}$ reduction, and $\mathrm{SO}_{4}{ }^{2-}$ removal usually occurs after $\mathrm{NO}_{3}{ }^{-}$ depletion (Whitmire and Hamilton, 2005). Consequently, the high remaining load of $\mathrm{NO}_{3}-$ in our CWs (FWS, $0.93 \mathrm{~g} \mathrm{~N} \mathrm{~m}^{-2} \mathrm{~d}^{-1}$; HSS, $0.73 \mathrm{~g} \mathrm{~N} \mathrm{~m}^{-2} \mathrm{~d}^{-1}$; and VSS, $1.73 \mathrm{~g} \mathrm{~N} \mathrm{~m}^{-2} \mathrm{~d}^{-1}$ ) (Table 1) prevented $\mathrm{SO}_{4}^{2-}$ reduction by sulfate-reducing bacteria.

\section{Phosphate and others element removal}

The efficiency of $\mathrm{PO}_{4}{ }^{3-}$ removal during the experiment ranged from $60 \%$ to $65 \%$, and the load removal was higher $(P \leq 0.05)$ in FWS $\left(0.18 \mathrm{~g} \mathrm{P} \mathrm{m}^{-2} \mathrm{~d}^{-1}\right)$ than in HSS and VSS $\left(0.15 \mathrm{~g} \mathrm{P} \mathrm{m}^{-2} \mathrm{~d}^{-1}\right)$ (Table 1). Lower $\mathrm{PO}_{4}^{3-}$ removal efficiency (30\%-40\%) was obtained in HSS planted with T. latifolia when the $\mathrm{PO}_{4}{ }^{3-}$ concentration was 2.7 times higher $(32 \mathrm{mg} \mathrm{P}$ $\mathrm{L}^{-1}$ ) than in our study (12 mg P L${ }^{-1}$ ) (Prystay and Lo, 2001), while Gagnon et al. (2010) observed a $30 \% \mathrm{PO}_{4}{ }^{3-}$ removal from hydroponic wastewater containing $57 \mathrm{mg} \mathrm{L}^{-1}$ of P. As filling materials such as sand and gravel, commonly used in VSS and HSS, provide very low capacity for P sorption and precipitation (Vymazal, 2007), plant uptake and microbial immobilization may also have contributed for P removal from the wastewater in our study.

The removal of $\mathrm{Mg}^{2+}, \mathrm{K}^{+}, \mathrm{Ca}^{2+}$, and $\mathrm{Cl}^{-}$from wastewater is seldom reported, although their importance for the functioning of CWs (Kadlec and Wallace, 2009) and for plant nutrient balance when treated water is recycled as irrigation water of greenhouse crops. As detailed in Table 1, HSS performed better than VSS $(P \leq 0.05)$ by removing $28 \%$ and $22 \%$ of $\mathrm{Cl}^{-}$and $\mathrm{Ca}^{2+}$, respectively, compared to $12 \%$ and $0 \%$. A better performance of HSS compared with FWS was also observed for $\mathrm{Cl}^{-}$and $\mathrm{Mg}^{2+}(P \leq 0.05)$.

Although the $\mathrm{Na}^{+}$content was negligible in effluents sampled for one year in commercial greenhouse facilities of our study, its concentration can accumulate in recirculating greenhouse nutrient solutions due to the irrigation water quality and the type of fertilizer used (Rozema et al., 2014). Typha latifolia used in two types of the investigated wetlands was proven to have a good phytodesalinization potential of $\mathrm{Na}^{+}$and $\mathrm{Cl}^{-}$in microcosm and constructed wetland environment (Rozema et al., 2014). Indeed, after five weeks of growth, T. latifolia did take up (grams of each ion accumulated per $\mathrm{m}^{2}$ of microcosm) up to $9.2 \mathrm{~g} \mathrm{~m}^{-2}$ of $\mathrm{Na}^{+}$and $27.2 \mathrm{~g} \mathrm{~m}^{-2}$ of $\mathrm{Cl}^{-}$(equivalent to $12 \% \mathrm{Na}^{+}$and $23 \% \mathrm{Cl}^{-}$of ions removed from greenhouse nutrient solution). On the other hand, Eichhornia crassipes was able to reduce by $70 \%$ the $\mathrm{Na}^{+}$ content in domestic sewage having an initial concentration of $2.3 \mathrm{mg} \mathrm{Na}^{+} \mathrm{L}^{-1}$ (Ajibade et al., 2013), while the removal efficiency was $9 \%$ for kitchen wastewater having an initial concentration of $17 \mathrm{mg} \mathrm{Na}^{+} \mathrm{L}^{-1}$ (Parwin and Paul, 2019). The use of hybrid wetland systems combined with large areas of macrophytes having a high potential to accumulate $\mathrm{Na}^{+}$ (e.g., T. latifolia up to $8.2 \mathrm{~g} \mathrm{Na}^{+} \mathrm{kg}^{-1}$ dry weight accumulated in biomass, Atriplex prostrate up to $21 \mathrm{~g} \mathrm{Na}^{+} \mathrm{kg}^{-1}$ dry weight and Salicornia europaea up to $38 \mathrm{~g} \mathrm{Na}^{+} \mathrm{kg}^{-1}$ dry weight) could then be a sustainable approach to remove the $\mathrm{Na}^{+}$content occurring in the nutrient solution of closed growing systems (Morteau, 2016).

\section{Nitrous oxide emissions and microbial activity}

Daily $\mathrm{N}_{2} \mathrm{O}$ fluxes in FWS varied $(P \leq 0.05)$ during the 19week experiment (300-3500 $\mathrm{mg} \mathrm{N} \mathrm{m}^{-2} \mathrm{~d}^{-1}$; Figure 2E). The averaged mean cumulative $\mathrm{N}_{2} \mathrm{O}$ emissions in FWS $(\sim 1586 \mathrm{mg}$ $\left.\mathrm{N} \mathrm{m}^{-2} \mathrm{~d}^{-1}\right)$ were 7 to 59 times higher than in HSS $(\sim 222 \mathrm{mg} \mathrm{N}$

TABLE 3. Mean populations of total aerobic and denitrifying microflora and fluorescein diacetate (FDA) hydrolysis measured at the outlets (period 1, first 8 weeks, $n=30$; period 2, weeks 9 to 19, $n=36$ ) of the three types of wetlands (free water surface flow, FWS; horizontal-subsurface flow, HSS; vertical-subsurface flow, VSS).

\begin{tabular}{cccc}
\hline & $\begin{array}{c}\text { Aerobic microflora } \\
\left(\times 10^{5}\right)\end{array}$ & $\begin{array}{c}\text { Denitrifying microflora } \\
\left(\times 10^{4}\right)\end{array}$ & $\begin{array}{c}\text { FDA hydrolysis }^{2} \\
\left(\mu \mathrm{g} \text { fluorescein } \mathrm{h}^{-1} \mathrm{~mL}^{-1}\right)\end{array}$ \\
\hline Period 1 & & & $34.4 \pm 5.6 \mathrm{a}$ \\
FWS & $1.1(0.3-3.7)$ & $3.0(0.9-9.9)$ & $9.6 \pm 1.2 \mathrm{~b}$ \\
HSS & $0.2(0.1-0.8)$ & $0.5(0.2-1.6)$ & $8.3 \pm 1.3 \mathrm{~b}$ \\
VSS & $0.1(0.0-0.5)$ & $0.5(0.2-1.7)$ & \\
Period 2 & & & $45.0 \pm 5.9 \mathrm{a}$ \\
FWS & $2.1(0.6-7.1)$ & $8.3(2.5-27.6)$ & $7.1 \pm 0.9 \mathrm{~b}$ \\
HSS & $0.6(0.2-1.9)$ & $1.1(0.3-3.8)$ & $2.2 \pm 0.3 \mathrm{c}$ \\
VSS & $0.5(0.1-1.6)$ & $0.9(0.3-2.9)$ & \\
\hline
\end{tabular}

${ }^{1}$ For aerobic and denitrifying microflora, means are most probable number $\mathrm{mL}^{-1}$, and values in parentheses represent the low and high confidence limits (95\%).

2 The means \pm standard errors followed by different letters are significantly different according to Tukey's test $(P \leq 0.05)$. 
$\left.\mathrm{m}^{-2} \mathrm{~d}^{-1}\right)$ and in VSS $\left(\sim 27 \mathrm{mg} \mathrm{N} \mathrm{m}^{-2} \mathrm{~d}^{-1}\right)$ (Table 2). Compared to daily $\mathrm{N}_{2} \mathrm{O}$ fluxes by agricultural soils $\left(0.2\right.$ to $540 \mathrm{mg} \mathrm{N} \mathrm{m}^{-2} \mathrm{~d}^{-1}$; Hénault et al., 2012), those by FWS were much higher, while the daily $\mathrm{N}_{2} \mathrm{O}$ fluxes by HSS $\left(100-600 \mathrm{mg} \mathrm{N} \mathrm{m}^{-2} \mathrm{~d}^{-1}\right)$ and VSS (1 to $100 \mathrm{mg} \mathrm{N} \mathrm{m}^{-2} \mathrm{~d}^{-1}$ ) (Figure 2E) were similar to or lower than the agricultural soils. The daily $\mathrm{N}_{2} \mathrm{O}$ flux is in line with greater microbial activity $(P \leq 0.05)$ in FWS than in HSS and VSS (Figure 2H, Table 3). The population of aerobic microflora was 4 to 10 times higher (Table 3 ) and released substantially $(P \leq 0.05)$ more $\mathrm{CO}_{2}$ (Table 2$)$ in FWS than in HSS or VSS, as indicated by the higher FDA hydrolysis $(P \leq 0.05)$ observed in the FWS (Table 3). Several enzymes can hydrolyze FDA and are involved in the decomposition of many types of tissue (Adam and Duncan, 2001). The high FDA activity, microbial counts, and $\mathrm{CO}_{2}$ emissions suggest the presence of substantial decomposition activity in the FWS throughout the experiment, indicating an additional $\mathrm{C}$ source for microbial activity. The negligible $\mathrm{CH}_{4}$ production in our $\mathrm{CWs}(<1 \mathrm{mg} \mathrm{C}$ $\mathrm{m}^{-2} \mathrm{~d}^{-1}$; Figure 2G; Table 2) indicates that the redox threshold below which methanogenesis occurs was not reached (Laanbroek, 2010), and microorganisms involved in the reduction of $\mathrm{NO}_{3}^{-}$had consumed most of the $\mathrm{C}$ available.

In comparison with FWS, the low $\mathrm{N}_{2} \mathrm{O}$ emissions (Figure 2e; Table 2) and the high efficiency at removing $\mathrm{NO}_{y}$ $\left(\mathrm{NO}_{3}-\mathrm{N}+\mathrm{NO}_{2}-\mathrm{N}\right)$ loading in HSS $(53 \%)$ than in FWS $(5 \%)$ (Figures 2A, B; Table 1) show a greater denitrification potential in HSS. Contrary to HSS, the high redox potential in the VSS, as shown by the active nitrification, likely inhibited the activity of denitrifiers. This observation is in line with the high $\mathrm{NO}_{3}-$ accumulation and low $\mathrm{N}_{2} \mathrm{O}$ emissions in the VSS (Figures 2A, E), resulting mainly from the activity of strictly aerobic chemolithotrophic bacteria (Vymazal, 2007).

Although the $\mathrm{O}_{2}$ concentration and COD: $\mathrm{N}$ ratio influence
$\mathrm{N}_{2} \mathrm{O}$ emissions, the high concentration of $\mathrm{NO}_{2}{ }^{-}$is the most important operational parameter leading to $\mathrm{N}_{2} \mathrm{O}$ emissions in wastewater treatment (Kampschreur et al., 2009; Kelso et al., 1997, 1999; Saeed and Sun, 2012; Zhang et al., 2014). Indeed, we observed a positive correlation $\left(\mathrm{r}^{2}=0.870 ; P<0.001\right)$ between cumulative $\mathrm{N}_{2} \mathrm{O}$ flux and $\mathrm{NO}_{2}^{-}$exposure in our CWs (Figure 3). Similarly, a strong positive relationship between $\mathrm{N}_{2} \mathrm{O}$ flux and $\mathrm{NO}_{2}$ exposure $\left(\mathrm{r}^{2}=0.945\right)$ was observed for VSS treating synthetic wastewater with different types of external C sources (Zhang et al., 2014). Under limited $\mathrm{O}_{2}$ concentration, it was also reported that a $\mathrm{NO}_{2}$ - concentration higher than $50 \mathrm{mg} \mathrm{N} \mathrm{L}^{-1}$ results in increased $\mathrm{N}_{2} \mathrm{O}$ production (Castro-Barros et al., 2016), which is in line with our FWS results where the outlet concentration of $\mathrm{NO}_{2}^{-}$was $\sim 57 \mathrm{mg} \mathrm{N} \mathrm{L}^{-1}$. As $\mathrm{N}_{2} \mathrm{O}$ is produced predominantly via the incomplete denitrification of $\mathrm{NO}_{3}{ }^{-}$in CWs (Lind et al., 2013), the removal of $\mathrm{NO}_{3}^{-}$ in our CWs was also correlated $\left(\mathrm{r}^{2}=0.483 ; P<0.001\right)$ with cumulative $\mathrm{N}_{2} \mathrm{O}$ flux (Figure 3 ).

The sharp decrease in $\mathrm{N}_{2} \mathrm{O}$ emissions and FDA hydrolysis at week 8 and 9 (Figures 2E, H) suggests that a change in microbial populations occurred in FWS. As E. crassipes were healthy at the beginning of the experiment, the long exposure to a high concentration of $\mathrm{NO}_{2}^{-}$had a phytotoxic effect (Oke, 1966), resulting in gradual plant death, affecting microbial activity, such as denitrifying microflora (Table 3).

\section{Conclusions}

Among the three types of CWs, with well-proven designs, HSS was the most efficient at removing $\mathrm{N}\left(1.29 \mathrm{~g} \mathrm{~N} \mathrm{~m}^{-2} \mathrm{~d}^{-1}\right)$, followed by FWS $\left(0.42 \mathrm{~g} \mathrm{~N} \mathrm{~m}^{-2} \mathrm{~d}^{-1}\right)$, while VSS $\left(0.15 \mathrm{~g} \mathrm{~N} \mathrm{~m}^{-2} \mathrm{~d}^{-1}\right)$ had poor performance. Although the FWS removed 59\% of the $\mathrm{NO}_{3}-\mathrm{N}$ from the inlet, they exhibited incomplete $\mathrm{NO}_{3}{ }^{-}$reduction, producing a very high concentration of $\mathrm{NO}_{2}{ }^{-}$in the

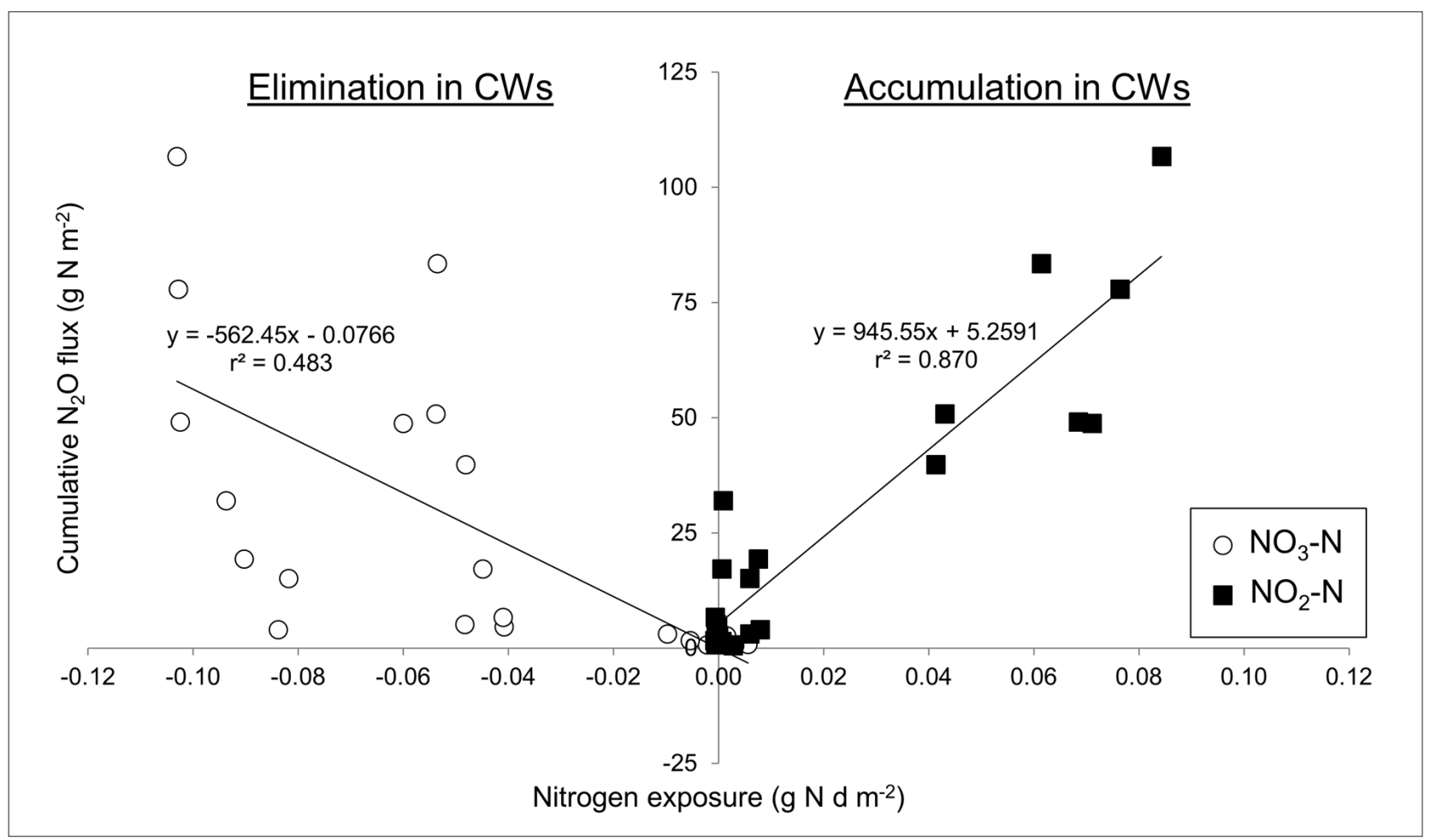

FIGURE 3. Relationship between $\mathrm{N}$ exposure forms and cumulative $\mathrm{N}_{2} \mathrm{O}$ flux from the three constructed wetlands (CWs) studied: free water surface flow, horizontal-subsurface flow, and vertical-subsurface flow. Both $\mathrm{NO}_{3}-\mathrm{N}_{\text {and }} \mathrm{NO}_{2}-\mathrm{N}$ exposure are calculated as the sum of the daily mean of the loading variations between the outlet and inlet of the CWs throughout the experiment (19 weeks). The negative and positive values of $\mathrm{NO}_{3}-\mathrm{N}$ and $\mathrm{NO}_{2}-\mathrm{N}$ show the elimination and accumulation of these elements in the CWs, respectively. 
outlet. In addition, the sustained high emissions of $\mathrm{N}_{2} \mathrm{O}$ from this type of CW are a drawback in terms of increased global warming. Because denitrification and DNRA are both mechanisms involved in the reduction of $\mathrm{NO}_{3}{ }^{-}$in $\mathrm{CWs}$, it is crucial while monitoring the elimination of $\mathrm{NO}_{3}{ }^{-}$to simultaneously monitor the accumulation of $\mathrm{NO}_{2}^{-}$and the production of $\mathrm{N}_{2} \mathrm{O}$, in order to obtain a high wastewater treatment performance.

In contrast with previous studies (Misiti et al., 2011; Zhao et al., 2010), a C:N ratio of 2.9 was not high enough to ensure the complete removal of $\mathrm{NO}_{3}^{-}$and, consequently, no substantial $\mathrm{SO}_{4}{ }^{2-}$ load removal in the three CWs was observed. On the other hand, all studied CWs showed comparable $\mathrm{P}$ removal (average of $63 \% \mathrm{PO}_{4}-\mathrm{P}$ ).

Although these commonly used CWs performed well for treating various types of wastewater, our study clearly showed that the best design for sustainable performance for the treatment of greenhouse wastewater highly loaded with nutrients was the HSS, confirming our hypothesis for $\mathrm{NO}_{3}-$ removal, but not for $\mathrm{SO}_{4}{ }^{2-}$ reduction due to a limitation of the carbon source. The HSS also had significantly lower $\mathrm{NO}_{2}-$ accumulation and $\mathrm{N}_{2} \mathrm{O}$ emissions than FWS, thus resulting in a lower environmental impact. Our study also showed that the use of FWS or lagoons to store wastewater coming from the greenhouse crops, constitutes an important environmental burden in terms of $\mathrm{N}_{2} \mathrm{O}$ emissions. Moreover, E. crassipes is not adapted to treat greenhouse wastewater rich in nutrients. Our previous study using three serial VSS CWs and treating greenhouse wastewater at the commercial scale shown a high efficiency to remove nitrate and phosphate from wastewater by up to $90 \%$ and $100 \%$, respectively (Lévesque et al., 2011). So, although HSS has shown a good efficiency to remove $\mathrm{NO}_{3}{ }^{-}$from greenhouse wastewater with low $\mathrm{N}_{2} \mathrm{O}$ emissions during treatment, the use of multiple and hybrid (VSS combined to HSS) CWs operated in series should be tested to improve the efficiency of removing nutrients, such as $\mathrm{NO}_{3}{ }^{-}$and $\mathrm{SO}_{4}{ }^{2-}$ than single HSS or VSS CWs (Vymazal, 2013b).

In conclusion, this study has shown that the use of HSS constitutes a sustainable option to treat greenhouse effluents before disposal, while FWS causes important environmental burden in terms of $\mathrm{N}_{2} \mathrm{O}$ emissions. However, sufficient organic carbon should be provided to maintain a complete denitrification and reduction of sulfate, and then reduce the environmental footprint related to the management of greenhouse effluents.

\section{Acknowledgments}

We thank Normand Bertrand and Claudine Ménard for their skillful technical assistance and constructive discussions. Funding was provided by Agriculture and Agri-Food Canada and by Laval University.

\section{References}

Adam, G., and Duncan, H. (2001). Development of a sensitive and rapid method for the measurement of total microbial activity using fluorescein diacetate (FDA) in a range of soils. Soil Biol. Biochem. 33, 943-951. https://doi.org/10.1016/S0038-0717(00)00244-3.

Ajibade, F.O., Adeniran, K.A., and Egbuna, C.K. (2013). Phytoremediation efficiencies of water hyacinth in removing heavy metals in domestic sewage (A case study of University of Ilorin, Nigeria). Int. J. Eng. Sci. 2 (12), 16-27.

Alleman, J.E. (1985). Elevated nitrite occurrence in biological wastewater treatment systems. Wat. Sci. Tech. 17, 409-419. https:// doi.org/10.2166/wst.1985.0147.
APHA (2005). Standard methods for the examination of water and wastewater. $21^{\text {st }}$ edn. (Washington, D.C.: American Public Health Association, American Water Works Association (AWWA), and American Environment Federation (AEF)).

Burton, D.L., Zebarth, B.J., Gillam, K.M., and MacLeod, J.A. (2008). Effect of split application of fertilizer nitrogen on $\mathrm{N}_{2} \mathrm{O}$ emissions from potatoes. Can. J. Soil Sci. 88(2), 229-239. https://doi.org/10.4141/ CJSS06007.

Castro-Barros, C.M., Rodriguez-Caballero, A., Volcke, E.I.P., and Pijuan, M. (2016). Effect of nitrite on the $\mathrm{N}_{2} \mathrm{O}$ and NO production on the nitrification of low-strength ammonium wastewater. Chem. Eng. J. 287, 269-276. https://doi.org/10.1016/j.cej.2015.10.121.

Dorais, M., Papadopoulos, A.P., and Gosselin, A. (2001). Influence of electric conductivity management on greenhouse tomato yield and fruit quality. Agronomie 21, 367-383. https://doi.org/10.1051/ agro:2001130.

Gagnon, V., Maltais-Landry, G., Puigagut, J., Chazarenc, F., and Brisson, J. (2010). Treatment of hydroponics wastewater using constructed wetlands in winter conditions. Water Air Soil Pollut. 212, 483-490. https://doi.org/10.1007/s11270-010-0362-8.

Gao, Y., Yi, N., Zhang, Z., Liu, H., and Yan, S. (2012). Fate of ${ }^{15} \mathrm{NO}_{3}$ and ${ }^{15} \mathrm{NH}_{4}{ }^{+}$in the treatment of eutrophic water using the floating macrophyte, Eichhornia crassipes. J. Environm. Qual. 41, 1653-1660. https://doi.org/10.2134/jeq2011.0324.

Gruyer, N., Dorais, M., Alsanius, B.W., and Zagury, G.J. (2013a). Simultaneous removal of nitrate and sulfate from greenhouse wastewater by constructed wetlands. J. Environm. Qual. 42, 12561266. https://doi.org/10.2134/jeq2012.0306.

Gruyer, N., Dorais, M., Zagury, G.J., and Alsanius, B.W. (2013b). Removal of plant pathogens from recycled greenhouse wastewater using constructed wetlands. Agric. Water Mgt. 117, 153-158. https://doi.org/10.1016/j.agwat.2012.11.009.

Hénault, C., Grossel, A., Mary, B., Roussel, M., and Léonard, J. (2012). Nitrous oxide emission by agricultural soils: A review of spatial and temporal variability for mitigation. Pedosphere 22(4), 426-433. https://doi.org/10.1016/S1002-0160(12)60029-0.

Kadlec, R.H., and Wallace, S.D. (2009). Treatment Wetlands, $2^{\text {nd }}$ edn. (Boca Raton, Florida: Taylor \& Francis Group, CRC Press Inc.).

Kampschreur, M.J., Temmink, H., Kleerebezem, R., Jetten, M.S.M., and Van Loosdrecht, M.C.M. (2009). Nitrous oxide emission during wastewater treatment. Water Res. 43, 4093-4103. https://doi. org/10.1016/j.watres.2009.03.001.

Kelso, B.H.L., Smith, R.V., Laughlin, R.J., and Lenno, S.D. (1997). Dissimilatory nitrate reduction in anaerobic sediments leading to river nitrite accumulation. Appl. Environ. Microbiol. 63(12), 46794685. https://doi.org/10.1128/AEM.63.12.4679-4685.1997.

Kelso, B.H.L., Smith, R.V., and Laughlin, R.J. (1999). Effects of carbon substrates on nitrite accumulation in freshwater sediments. Appl. Environ. Microbiol. 65(1), 61-66. https://doi.org/10.1128/ AEM.65.1.61-66.1999.

Kern, J., and Idler, C. (1999). Treatment of domestic and agricultural wastewater by reed bed systems. Ecol. Eng. 12, 13-25. https://doi. org/10.1016/S0925-8574(98)00051-2.

Kim, J.H., Guo, X., and Park, H.S. (2008). Comparison study of the effects of temperature and free ammonia concentration on nitrification and nitrite accumulation. Process Biochem. 43, 154160. https://doi.org/10.1016/j.procbio.2007.11.005.

Laanbroek, H.J. (2010). Methane emission from natural wetlands: Interplay between emergent macrophytes and soil microbial processes. A mini-review. Ann. Botany 105, 141-153. https://doi. org/10.1093/aob/mcp201. 
Lee, C., Fletcher, T.D., and Sun, G. (2009). Nitrogen removal in constructed wetland systems. Eng. Life Sci. 9, 11-22. https://doi. org/10.1002/elsc.200800049.

Lévesque, V., Dorais, M., Gravel, V., Ménard, C., Antoun, H., Rochette, P., and Roy, R. (2011). The use of artificial wetlands to treat greenhouse effluents. Acta Hortic. 893, 1185-1192. https://doi.org/10.17660/ ActaHortic.2011.893.138

Lind, L.P.D., Audet, J., Tonderski, K., and Hoffmann, C.C. (2013). Nitrate removal capacity and nitrous oxide production in soil profiles of nitrogen loaded riparian wetlands inferred by laboratory microcosms. Soil Biol. Biochem. 60, 156-164. https://doi. org/10.1016/j.soilbio.2013.01.021.

Mander, Ü., Dotro, G., Ebie, Y., Towprayoon, S., Chiemchaisri, C., Furlan Nogueira, S., Jamsranjav, B., Kasak, K., Truu, J., Tournebize, J., and Mitsch, W.J. (2014). Greenhouse gas emission in constructed wetlands for wastewater treatment: A review. Ecol. Eng. 66, 19-35. https://doi.org/10.1016/j.ecoleng.2013.12.006.

McCarty, G.W., Mookherji, S., and Angier, J.T. (2007). Characterization of denitrification activity in zones of groundwater exfiltration within a riparian wetland ecosystem. Biol. Fert. Soils 43, 691-698. https:// doi.org/10.1007/s00374-006-0151-0.

Misiti, T.M., Hajaya, M.G., and Pavlostathis, S.G. (2011). Nitrate reduction in a simulated free-water surface wetland system. Water Res. 45, 5587-5598. https://doi.org/10.1016/j.watres.2011.08.019.

Morteau, B. (2016). Salt contaminated water phytotreatment by constructed wetland. In Sabkha Ecosystems, Vol. V: The Americas. Tasks for Vegetation Science 48, M.A. Khan et al., eds. https://doi. org/10.1007/978-3-319-27093-7_14.

Murphy, J., and Riley, J.P. (1962). A modified single solution method for the determination of phosphate in natural waters. Anal. Chim Acta 27, 31-36. https://doi.org/10.1016/S0003-2670(00)88444-5.

Oke, O.L. (1966). Nitrite toxicity to plants. Nature 212, 528. https:// doi.org/10.1038/212528a0.

Park, J.B.K., Craggs, R.J., and Sukias, J.P.S. (2008). Treatment of hydroponic wastewater by denitrification filters using plant prunings as the organic carbon source. Bioresour. Technol. 99, 27112716. https://doi.org/10.1016/j.biortech.2007.07.009.

Parwin, R., and Paul, K.K. (2019). Phytoremediation of kitchen wastewater using Eichhornia crassipes. J. Environ. Eng. 145(6), 04019023. https://doi.org/10.1061/(ASCE)EE.19437870.0001520

Postgate, J.R. (1984). The Sulfate-Reducing Bacteria, $2^{\text {nd }}$ edn. (Cambridge, U.K.: Cambridge University Press).

Prystay, W., and Lo, K.V. (2001). Treatment of greenhouse wastewater using constructed wetlands. J. Environm. Sci. Heal. B. 36, 341-353. https://doi.org/10.1081/PFC-100103574.

Reddy, K.R., and DeLaune, R.D. (2008). Biogeochemistry of Wetlands: Science and Applications (Boca Raton, Florida: Taylor \& Francis Group, CRC Press Inc.). https://doi.org/10.1201/9780203491454.

Rochette, P., and Bertrand, N. (2008). Soil-surface gas emissions. In Soil Sampling and Methods of Analysis, $2^{\text {nd }}$ ed., M.R. Carter, and E.G. Gregorich, eds. (Boca Raton, Florida: Taylor \& Francis Group, CRC Press Inc.), p. 851-861. https://doi.org/10.1201/9781420005271. ch65.

Rozema, E.R., Gordon, R.J., and Zheng, Y. (2014). Plant species for the removal of $\mathrm{Na}$ and $\mathrm{Cl}$ from greenhouse nutrient solution. HortScience 49(8), 1071-1075. https://doi.org/10.21273/HORTSCI.49.8.1071.

Saeed, T., and Sun, G. (2012). A review on nitrogen and organics removal mechanisms in subsurface flow constructed wetlands: Dependency on environmental parameters, operating conditions and supporting media. J. Environm. Mgt. 112, 429-448. https://doi. org/10.1016/j.jenvman.2012.08.011.
Tanner, C.C. (1996). Plants for constructed wetland treatment systems - A comparison of the growth and nutrient uptake of eight emergent species. Ecol. Eng. 7, 59-83. https://doi. org/10.1016/0925-8574(95)00066-6.

Vymazal, J. (2007). Removal of nutrients in various types of constructed wetlands. Sci. Total Environm. 380, 48-65. https://doi. org/10.1016/j.scitotenv.2006.09.014.

Vymazal, J. (2008a). Constructed wetlands, subsurface flow. In Encyclopedia of Ecology, Vol. 1, S.E. Jorgensen, and B. Fath, eds. (Amsterdam: Elsevier), p. 748-764. https://doi.org/10.1016/B978008045405-4.00080-X.

Vymazal, J. (2008b). Constructed wetlands, surface flow. In Encyclopedia of Ecology, Vol. 1, S.E. Jorgensen, and B. Fath, eds. (Amsterdam: Elsevier), p. 765-776. https://doi.org/10.1016/B978008045405-4.00079-3.

Vymazal, J. (2013a). Emergent plants used in free water surface constructed wetlands: A review. Ecol. Eng. 61 Part B, 582-592. https://doi.org/10.1016/j.ecoleng.2013.06.023.

Vymazal, J. (2013b). The use of hybrid constructed wetlands for wastewater treatment with special attention to nitrogen removal: A review of a recent development. Water Res. 47, 4795-4811. https://doi.org/10.1016/j.watres.2013.05.029.

Werker, A.G., Dougherty, J.M., McHenry, J.L., and Van Loon, W.A. (2002). Treatment variability for wetland wastewater treatment design in cold climates. Ecol. Eng. 19, 1-11. https://doi.org/10.1016/ S0925-8574(02)00016-2.

White, S.A. (2013). Wetland technologies for nursery and greenhouse compliance with nutrient regulations. HortScience. 48(9), 11031108. https://doi.org/10.21273/HORTSCI.48.9.1103.

Whitmire, S.L., and Hamilton, S.K. (2005). Rapid removal of nitrate and sulfate in freshwater wetland sediments. J. Environ. Qual. 34, 2062-2071. https://doi.org/10.2134/jeq2004.0483.

Wu, H., Zhang, J., Hao Ngo, H., Guo, W., Hu, Z., Liang, S., Fan, J., and Liu, H. (2015). A review on the sustainability of constructed wetlands for wastewater treatment: Design and operation. Bioresour. Technol. 175, 594-601. https://doi.org/10.1016/j.biortech.2014.10.068.

Wu, S., Kuschk, P., Brix, H., Vymazal, J., and Dong, R. (2014). Development of constructed wetlands in performance intensifications for wastewater treatment: A nitrogen and organic matter targeted review. Water Res. 57, 40-55. https://doi. org/10.1016/j.watres.2014.03.020.

Yi, N., Gao, Y., Long, X.H., Zhang, Z.Y., Guo, J.Y., Shao, H.B., Zhang, Z.H., and Yan, S.H. (2014). Eichhornia crassipes cleans wetlands by enhancing the nitrogen removal and modulating denitrifying bacteria community. CLEAN - Soil Air Water 42(5), 664-673. https://doi.org/10.1002/clen.201300211.

Zhang, L., Xia, X., Zhao, Y., Xi, B., Yan, Y., Guo, X., Xiong, Y., and Zhan, J. (2011). The ammonium nitrogen oxidation process in horizontal subsurface flow constructed wetlands. Ecol. Eng. 37, 1614-1619. https://doi.org/10.1016/j.ecoleng.2011.06.020.

Zhang, M., Zhao, L., Mei, C., Yi, L., and Hua, G. (2014). Effects of plant material as carbon sources on TN removal efficiency and $\mathrm{N}_{2} \mathrm{O}$ flux in vertical-flow constructed wetlands. Water Air Soil Pollut. 225(11), 1-11. https://doi.org/10.1007/s11270-014-2181-9.

Zhao, Y.J., Liu, B., Zhang, W.G., Ouyang, Y., and An, S.Q. (2010). Performance of pilot-scale vertical-flow constructed wetlands in responding to variation in influent $\mathrm{C} / \mathrm{N}$ ratios of simulated urban sewage. Bioresour. Technol. 101, 1693-1700. https://doi. org/10.1016/j.biortech.2009.10.002. 
Received: Jan. 13, 2018

Accepted: Jul. 23, 2019

Addresses of authors:

V. Lévesque ${ }^{1}, \mathrm{H}$. Antoun ${ }^{1}$, P. Rochette ${ }^{2}$ and M. Dorais ${ }^{3, *}$

${ }^{1}$ Department of Soils and Agri-Food Engineering \& Centre de recherche et d'innovation sur les végétaux, Faculté des Sciences de l'agriculture et de l'alimentation, Université Laval, Quebec City, QC, G1V 0A6, Canada

${ }^{2}$ Quebec Research and Development Centre, Agriculture and Agri-Food Canada, Quebec City, QC, G1V 2J3, Canada

${ }^{3}$ Département de phytologie, Centre de recherche et d'innovation sur les végétaux, Faculté des Sciences de l'agriculture et de l'alimentation, Université Laval, Québec, QC, G1V 0A6, Canada

* Corresponding author; E-mail: Martine.Dorais.1@ulaval.ca Tel.: +1(418) 656-2131, ext. 403939;

Fax: +1(418) 656-3515

SUPPLEMENTAL INFORMATION - TABLE S1. Mineral concentrations of greenhouse wastewater.

\begin{tabular}{lc}
\hline Parameters & Effluent $^{1}$ \\
\hline $\mathrm{NO}_{3}-\mathrm{N}\left(\mathrm{mg} \mathrm{L}^{-1}\right)$ & 91.8 \\
$\mathrm{NO}_{2}-\mathrm{N}\left(\mathrm{mg} \mathrm{L}^{-1}\right)$ & 3.2 \\
$\mathrm{NH}_{4}-\mathrm{N}\left(\mathrm{mg} \mathrm{L}^{-1}\right)$ & 44.1 \\
$\mathrm{PO}_{4}-\mathrm{P}\left(\mathrm{mg} \mathrm{L}^{-1}\right)$ & 12.1 \\
$\mathrm{~K}^{+}\left(\mathrm{mg} \mathrm{L}^{-1}\right)$ & 541.6 \\
$\mathrm{SO}_{4}-\mathrm{S}\left(\mathrm{mg} \mathrm{L}^{-1}\right)$ & 313.1 \\
$\mathrm{Ca}^{2+}\left(\mathrm{mg} \mathrm{L}^{-1}\right)$ & 234.3 \\
$\mathrm{Mg}^{2+}\left(\mathrm{mg} \mathrm{L}^{-1}\right)$ & 134.1 \\
$\mathrm{Cl}^{-}\left(\mathrm{mg} \mathrm{L}^{-1}\right)$ & 83.1 \\
$\mathrm{EC}\left(\mathrm{mS} \mathrm{cm}^{-1}\right)^{2}$ & 5.2 \\
$\mathrm{pH}$ & 6.2 \\
\hline
\end{tabular}

${ }^{1}$ Based on average analyses of wastewaters sampled for one year in commercial greenhouses located in Eastern Canada.

${ }^{2}$ Electrical conductivity (EC).

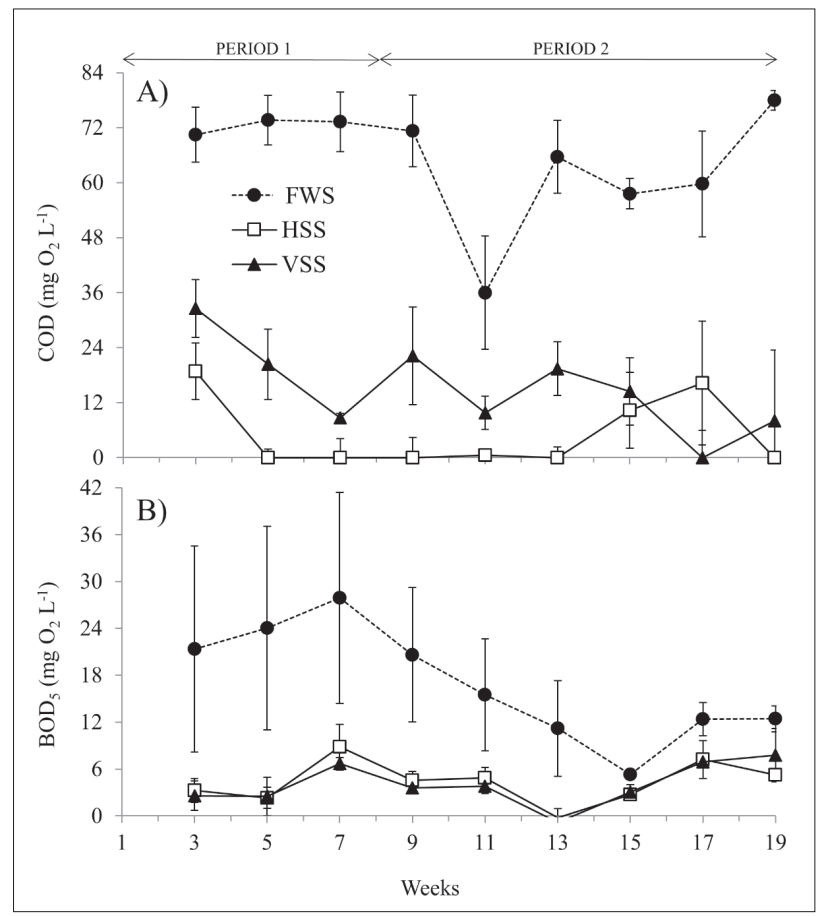

SUPPLEMENTAL INFORMATION - FiguRE S1. Chemical oxygen demand (COD) (a) and biochemical oxygen demand $\left(\mathrm{BOD}_{5}\right)(\mathrm{b})$ of the effluents of the three constructed wetlands (CWs) studied: free water surface flow (FWS), horizontalsubsurface flow (HSS), and vertical-subsurface flow (VSS). Data are means \pm standard errors of outlet concentrations of $\mathrm{COD}$ and $\mathrm{BOD}_{5}(n=6)$ in the tested wetlands. The inlet concentrations before entering the CWs were $0.0 \pm 1.7 \mathrm{mg}$ $\mathrm{COD} \mathrm{L}^{-1}$ and $3.6 \pm 0.5 \mathrm{mg} \mathrm{BOD}_{5} \mathrm{~L}^{-1}$. 